\title{
MICROBIAL CHARACTERIZATION OF JAZAN SABKHA IN SAUDI ARABIA
}

\author{
ALBOKARI, M. A. ${ }^{1}-$ ÇINAR, S. ${ }^{2}-$ MUTLU, M. B. ${ }^{2^{*}}$ \\ ${ }^{I}$ Nuclear Science Research Institute (NSRI), King Abdulaziz City for Science and Technology \\ (KACST), Riyadh, Saudi Arabia \\ ${ }^{2}$ Anadolu University, Faculty of Science, Biology Department, Eskişehir, Turkey \\ *Corresponding author \\ e-mail:mbmutlu@anadolu.edu.tr \\ (phone: +90-222-335-0580; fax: +90-222-320-4910) \\ (Received $6^{\text {th }}$ Dec 2016; accepted $8^{\text {th }}$ Mar 2017)
}

\begin{abstract}
Prokaryotic diversity of the Jazan sabkha, Saudi Arabia was investigated by using culture dependent techniques and 454 pyrosequencing. While representatives of the Salinibacteraceae and Rubidibacteraceae families were the predominant groups within bacterial community, comprising the $38.4 \%$ and $33.0 \%$ of all bacterial OTUs (respectively), archaeal community was dominated by the members of the Halobacteriaceae family, constituting $92.8 \%$ of all archaeal reads. Salinibacter and Halorhabdus were the most represented known bacterial and archaeal phylotypes in the community. The novel archaeal phylogroups appeared to be dominant, which made up $71.6 \%$ of all archaeal reads. Representatives of the bacterial phyla Firmicutes, Proteobacteria and Actinobacteria were cultured (Arhodomonas, Halobacillus, Virgibacillus, Halomonas, Actinopolyspora, Tamilnaduibacter). Haloarchaeal strains belonging to the genera Haloferax and Halogeometricum were isolated as well. Diversity and species richness of archaeal assemblages were higher than those of bacterial assemblages, revealed with rarefaction analysis and diversity indices.
\end{abstract}

Keywords: Halobacteriaceae, Salinibacter, halophilic bacteria/archaea, pyrosequencing

\section{Introduction}

Halophiles are found in all the three domains of life such as Archaea (e.g., Halobacterium sp.), Bacteria (e.g., Halobacillus sp.) and Eukaryotes (e.g., green algae, Dunaliella salina, brine shrimp, Artemia franciscana and halophytic plant, Atriplex halimus) (DasSarma and DasSarma, 2012).

"Sabkha" is an Arabic word that is used to express salt-encrusted flat surfaces. Such arid environments are common in the world, e.g. the coast of Baja California (Mexico) and Sinai Peninsula (Egypt) (Akili and Torrance, 1981). There are many coastal sabkhas along the shoreline of the Red Sea and Arabian Gulf, and inland sabkhas in Arabian Peninsula (Powers et al., 1966).

Jazan is a town in southwestern Saudi Arabia bordering the Red Sea and located on a salt dome (Dhowian, 2015). Jazan sabkha belongs to the group of the coastal sabkha which is flooded by seawater and exposed to UV-irradiation, temperature, and desiccation. Hyper saline regions differ from each other in terms of salt concentration, chemical composition and geographical location, which determine the nature of inhabitant microorganisms. These environments are predominantly occupied by both extremely halophilic and halotolerant microorganisms, for example, Halobacterium sp., Haloferax sp., Haloarcula sp., Halobacillus sp., Salinibacter ruber, Virgibacillus salarius, Bacillus spp. and Micrococcus luteus (Paterekt and Smith, 1985; Arahal et al., 1996; Anton et al., 2002; Solanki and Kothari, 2012; Solomon and Viswalingam, 2013). 
There is an expanding interest for halophilic microbes due to their biotechnological importance as sources of halophilic enzymes, fermentation of soy and fish sauce, biological treatment of saline wastewater and production of $\beta$-carotene, compatible solutes, bioplastics and bio fuel (Oren, 2010; Li and Yu, 2012). Therefore revealing the microbial diversity of these hypersaline areas is very important.

The bacterial groups in saline environment be halophilic and halotolerant microscopic organisms of different functionalities i.e sulfur oxidization, phosphate solubilization, cellulose corruption, anti-toxin and compounds creation and so forth (Holguin et al., 2001)

There are several reports on soil properties and constraction problems of sabkhas in Arabian Peninsula, on the other hand microbial compositions were poorly studied (Akili and Torrance, 1981; Baati et al., 2010; Basyoni and Aref, 2015). The aim of this study to reveal prokaryotic assemblage of Jazan sabkha which was analyzed with 16S rRNA gene-based methods.

\section{Materials and Methods}

\section{Sampling Area}

Sampling was carried out from the surface salt layer of Jazan sabkha (June, 2013). Jazan is a town in southwestern Saudi Arabia bordering the Red Sea and located on a salt dome The study area is located at $16^{\circ} 40^{\prime} 00.38^{\prime \prime} \mathrm{N}$ and $42^{\circ} 44^{\prime} 23.27^{\prime \prime} \mathrm{E}$ in southwest of Saudi Arabia. Each sample was collected into $50 \mathrm{ml}$ sterile FALCON tubes (Becton Dickinson) with sterile spatula, and kept at room temperature until use.

\section{Total DNA Extraction and Pyrosequencing}

GV filter $(0.22-\mu \mathrm{m}$ pore size, Durapore, Millipore) was used to collect microorganisms. Lysis of the microorganisms were carried out with the addition of the extraction buffer (100 mM Tris- $\mathrm{HCl}$ and $100 \mathrm{mM}$ EDTA pH 8.0), lysozyme (3 mg/mL), proteinase $\mathrm{K}(150 \mathrm{mg} / \mathrm{mL})$ and $10 \%$ sodium dodecyl sulfate and the mixture was incubated at $37^{\circ} \mathrm{C}$. After the addition of $\mathrm{NaCl}(5 \mathrm{M})$ and $\mathrm{CTAB}$ solution $(10 \% \mathrm{CTAB}$, $0.7 \mathrm{M} \mathrm{NaCl}$ ), the mixture was treated with liquid nitrogen and then put in a water bath $\left(65^{\circ} \mathrm{C}\right)$. Purification and precipitation of the DNA were carried out by using phenolchloroform-isoamyl alcohol (25:24:1) and ethanol. Total DNA was resuspended in Milli-Q water. Pyrosequencing were carried out by ChunLab Inc. (Seoul, South Korea) using Roche 454 GS FLX+/Junior system. Primers targeted the V1-V3 region of the $16 \mathrm{~S}$ rRNA gene. The reads were assigned into operational taxonomic units (OTUs) at 3\% dissimilarity level, by using CD-HIT program and EzTaxon-e database (Kim et al., 2012; Lane et al., 1985; Li et al., 2011). The determination of the community composition and the statistical analyses were carried out using CLcommunity ${ }^{\mathrm{TM}}$ program (ChunLab Inc., South Korea).

\section{Cultivation and Sequencing}

The sample was serially diluted (original, $10^{-2}, 10^{-4}, 10^{-6}$ ) and inoculated on plates containing 18\% and 23\% modified growth medium (MGM) (Dyall-Smith, 2009). The incubation was carried out at $37^{\circ} \mathrm{C}$ for four weeks. Colonies were restreaked on the same medium. The colonies were boiled in Milli-Q water for extracting DNA. 16S rRNA genes of the isolates were amplified by universal primers including $1492 \mathrm{r}$ ( $5^{\prime}$ - 
GGTTACCTTGTTACGACTT-3'), 27f (5'-AGAGTTTGATCATGGCTCAG-3') (Lane et al., 1985) and 21f (5'-TTCCGGTTGATCCTGCCGGA-3') (DeLong, 1992). Polymerase chain reactions (PCR) products were digested with HinfI and MboI restriction enzymes (Fermentas) $\left(37^{\circ} \mathrm{C}\right.$, overnight). ARDRA patterns were visualized using $2 \%$ agarose gel. Some of the PCR products were purified (Wizard ${ }^{\circledR}$ SV Gel and PCR Clean-Up System; Promega) and sequenced (CEQ ${ }^{\mathrm{TM}} 8000$ DNA sequencer; Beckman Coulter). The sequences were compared with the data in GenBank using BLAST and aligned with MUSCLE program (Edgar, 2004). The phylogenetic trees were constructed by using PhyML (Dereeper et al., 2008). Values of the branch points obtained from 100 bootstrap replicates.

\section{Nucleotide Accession Numbers}

The sequences have been deposited in the GenBank database under accession numbers: KJ401317-KJ401326.

\section{Results}

\section{Isolated Microorganisms}

Viable counts were made on $18 \%$ and $23 \%$ MGM plates, varied between $1.8 \times 10^{4}$ $4.4 \times 10^{4} \mathrm{cfu} / \mathrm{mL}$. 45 colonies were chosen for further analysis. 16S rRNA genes of the chosen colonies were amplified with polymerase chain reaction (PCR) by using archaea- and bacteria-specific primers. It was determined that 33 of them belonged to Bacteria and 12 of them belonged to Archaea. PCR products of the 16S rRNA genes were analyzed by ARDRA, yielded 2 patterns for Archaea and 8 patterns for Bacteria. The representatives of each pattern were chosen for sequencing revealed that the presence of genera Haloferax, Halogeometricum, Arhodomonas, Halobacillus, Virgibacillus, Halomonas, Tamilnaduibacter and Actinopolyspora. Phylogenetic analysis of archaeal and bacterial isolates are shown in Fig. 1 and Fig. 2.

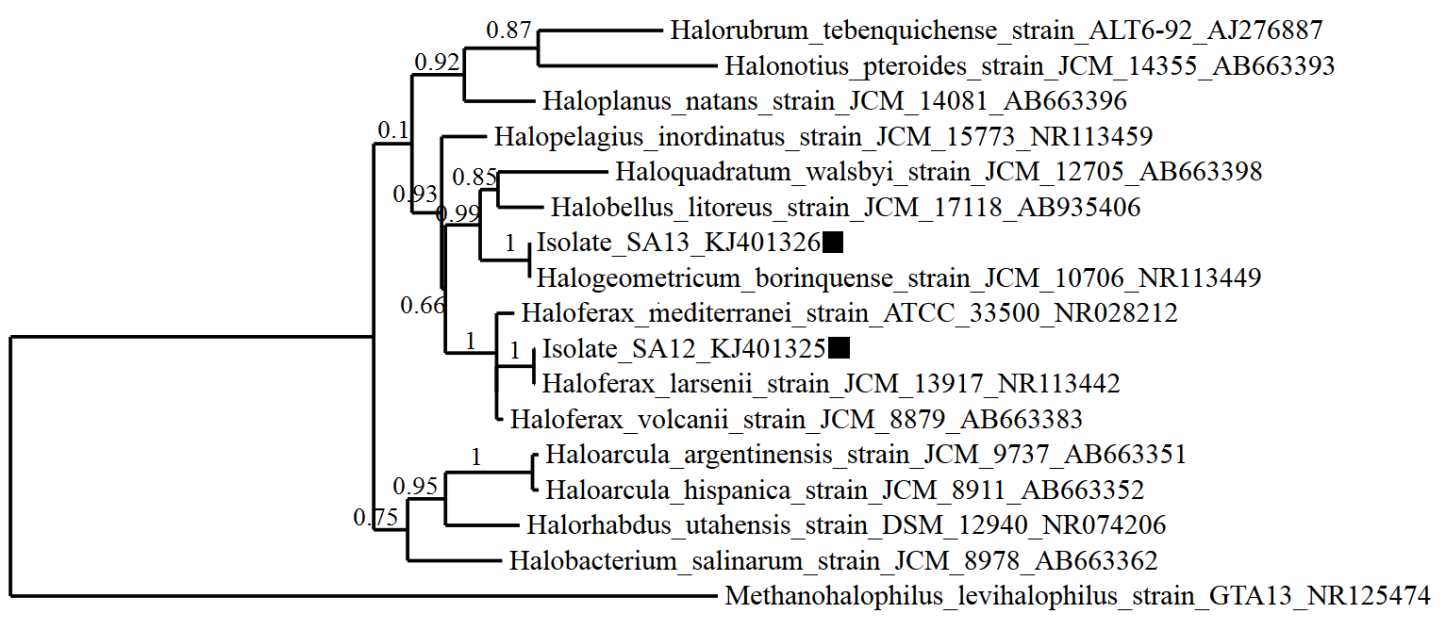

0.3

Figure 1. Maximum-likelihood phylogenetic analysis was performed using PhyML program (http://www.phylogeny.fr). Black squares represent the sequences of the archaeal isolates obtained in this study. 




Figure 2. Maximum-likelihood phylogenetic analysis was performed. Black squares represent the sequences of the bacterial isolates obtained in this study.

\section{Taxonomic Composition and Statistical Analysis}

7183 and 5719 high quality reads were obtained for Archaea and Bacteria (respectively). The number of the archaeal OTUs (1686) were approximately two-fold of the bacterial OTUs (851). The species richness and the diversity of the community were predicted by using Ace and Chaol estimators and Shannon-Wiener indices, showed that the archaeal populations were more diverse than the bacterial populations (Fig. 3, Table 1).

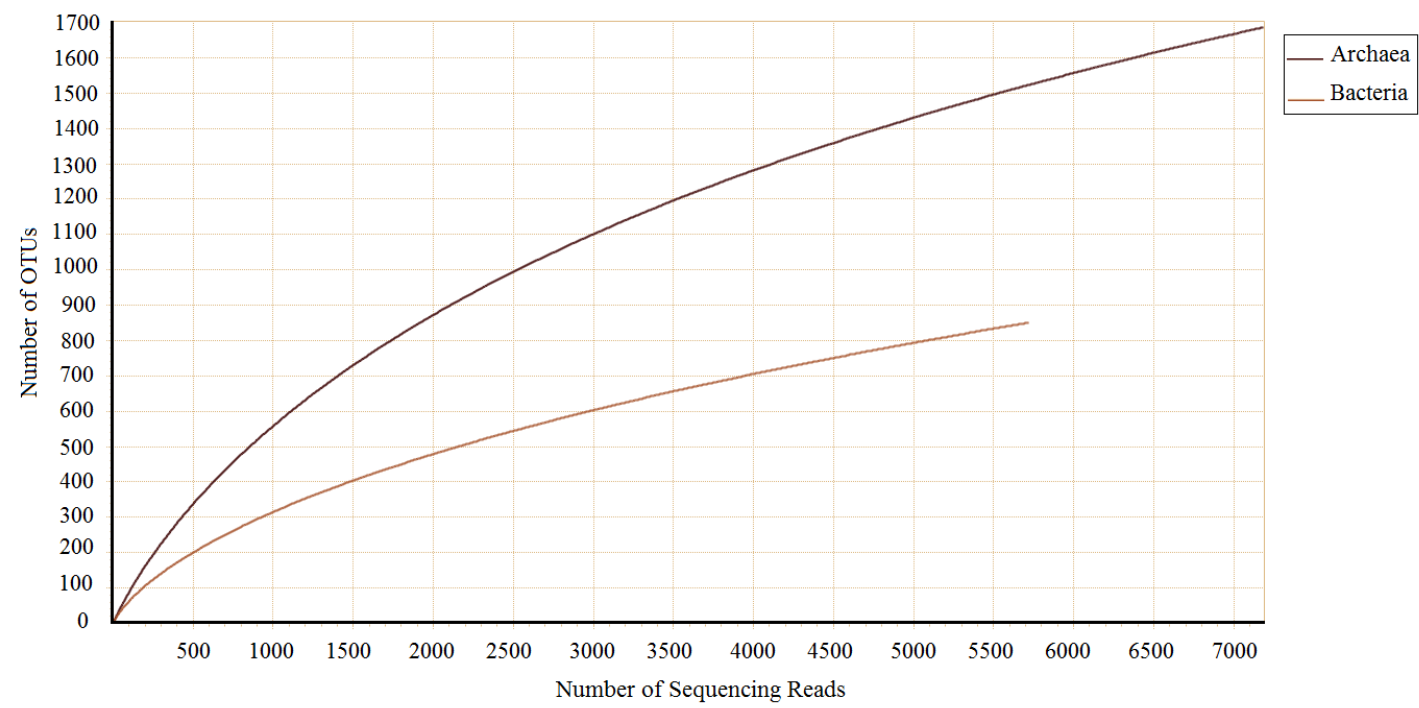

Figure 3. Rarefaction curves generated from the pyrosequencing reads (cut-off value at $97 \%$ similarity). 
Table 1. Pyrosequencing data and diversity indices of the archaeal and bacterial populations of Jazan sabkha

\begin{tabular}{llllllll} 
Sample & Valid reads & ARL & OTUs & Ace & Chao1 & $\boldsymbol{H}^{\prime}$ & Goods Lib. Coverage \\
\hline Archaea & 7183 & 426.8 & 1686 & 2589.8 & 2543.2 & 6.61 & 0.90 \\
Bacteria & 5719 & 401.1 & 851 & 2129.1 & 1572.7 & 5.08 & 0.92 \\
\hline
\end{tabular}

ARL - Average read length

H' - Shannon-Wiener diversity index

A

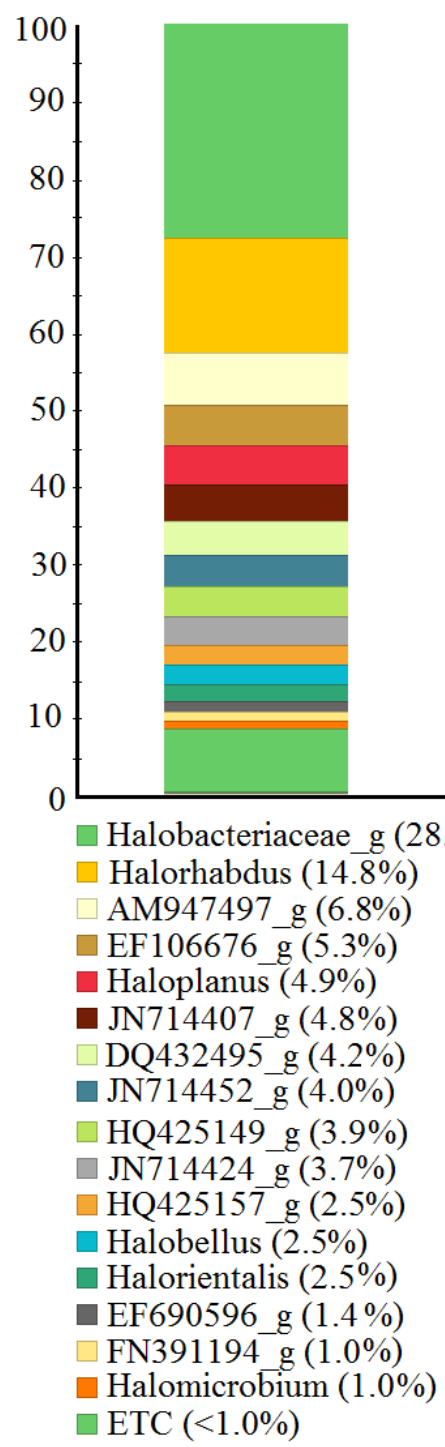

B

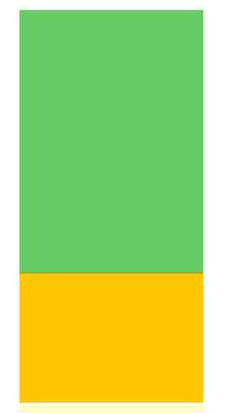

C

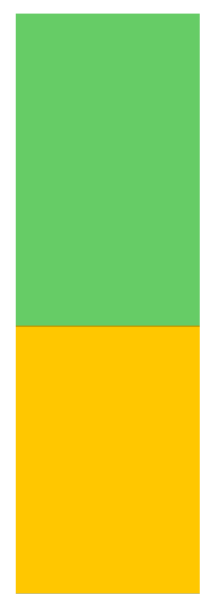

Bacteroidetes $(40.8 \%)$

$\square$ Salinibacter (34.3\%)

$\square$ Euhalothece (16.7\%)

EF105669 g (11.6\%)

Rubidibacteraceaee_g (4.6\%)

- Salinibacteraceae g (4.0\%)

Halospina $(3.2 \%)$

JX24066_g (3.3\%)

Rhodospirillaceae_g (1.6\%)

$\square$ AB533907 g (1.3\%)

$\square \operatorname{ETC}(<1.0 \%)$

$\square$ Cyanobacteria $(34.6 \%)$

Proteobacteria (11.1\%)

$\square$ JX240660_p (4.0\%)

-Planctomycetes $(2.3 \%)$

口OP1 $(1.8 \%)$

Gemmatimonadetes (1.7\%)

$\square \operatorname{ETC}(<1.0 \%)$

Figure 4. Bar charts displaying the taxonomic composition for archaeal genera $(\boldsymbol{A})$, bacterial genera $(\boldsymbol{B})$ and bacterial phyla $(\boldsymbol{C})$ (the genera assigned with $94.5 \%$ cutoff value).

The majority of the archaeal OTUs were within the Euryarchaeota $(99.5 \%$ of the archaeal reads) phylum. Thaumarchaeota related phylotypes were also detected, but their proportion was very low $(0.4 \%)$. A novel haloarchaeal phylogroup comprised 
$28.0 \%$ of the total archaeal community, followed by Halorhabdus (14.8\%), Haloplanus (4.9\%), Halobellus (2.5\%) and Halorientalis (2.2\%) (Fig. 4). The remaining known genera constituted small fraction of the archaeal community, included Halobacterium, Halomicroarcula, Halosimplex, Salinigranum, Salinirubrum, Haloferax, Halobaculum, Salarchaeum, Halorussus, Natrinema, Haloarcula and Crenarchaeum. The most represented bacterial OTUs were within the Bacteroidetes $(40.8 \%)$ and Cyanobacteria (34.6\%) phyla followed by Proteobacteria (11.1\%) (Fig. 4). Salinibacter was the predominant phylotype, which made up $34.3 \%$ of the bacterial reads. Most of the cyanobacterial reads were within the Rubidibacteraceae family.

\section{Discussion}

Bacterial diversity in sabkha ecosystems were investigated previously El Hidri et al. (2013) by using culture-dependent techniques revealed that the isolates were affiliated with Firmicutes, Actinobacteria, Proteobacteria phyla of which representatives also isolated in our study. The strains belong to Oceanobacillus, Virgibacillus, Halobacillus, Piscibacillus, Brevibacillus, Salinicoccus, Salimicrobium, Marinococcus, Halomonas, Leucobacter, Arthrobacter and Nesterenkonia genera were previously isolated from the Sabkhet El Melah and Sabkhet Ennaouel. The strains of Halobacillus, Virgibacillus and Halomonas were also isolated from the Jazan sabkha in our study, of which sequences were closely related with the sequences of the isolates those obtained from different hypersaline environments in China (Li et al., 2011; McKay et al., 2016; Meklat et al., 2011; Mesbah et al., 2007; Montalvo-Rodriguez et al., 1998; Powers et al., 1966; Saralov et al., 2012; Verma et al., 2015). The sequences of the strains of Actinopolyspora, Arhodomonas and Tamilnaduibacter were similar to sequences of the isolates those recovered from the soil (Algeria), brine (Russia) and salt pan (India) (respectively) (Li et al., 2011; Montalvo-Rodriguez et al., 1998; Saralov et al., 2012).

Archaeal isolates belonged to Haloferax and Halogeometricum genera of which sequences were closely related with the sequences of the isolates previously obtained from the solar salterns in China (Xu et al., 2007) and Puerto Rico (Montalvo-Rodriguez et al., 1998). Very few sequences affiliated with the isolated group detected within the pyrosequencing reads indicated that the cultured species comprised small proportion of the community.

Most of the archaeal reads were assigned to unknown genera, showed similarity with the sequences recovered from the clone libraries from different hypersaline environments in previous studies (Emmerich et al., 2012; Mesbah et al., 2007; Wang et al., 2011). Within the known archaeal genera, Halorhabdus phylotypes appeared to be relatively abundant and related sequences were retrieved from the clone libraries of Tunisian solar saltern (Baati et al., 2010).

McKay et al. (2016) investigated microbiota of sabkha in Rub'al Khali (Liwa Oasis, United Arab Emirates) by using $16 \mathrm{~S}$ rRNA gene cloning, revealed that surface layer of the sabkha mostly composed of phyla Bacteroidetes ( 63\%), Proteobacteria $(\sim 17 \%)$ and Cyanobacteria $(\sim 3 \%)$. We obtained similar results, but cyanobacterial phylotypes were more abundant $(\sim 35 \%)$ in our study. The most represented bacterial OTUs were closely related with Salinibacter, shared similarity with the sequences of the clones those recovered from hypersaline sediment in Death Valley National Park, California (Kim et al., 2012). Cyanobacterial sequences clustered mostly within the Euhalothece group, related sequences earlier obtained from the microbial mats of Guerrero Negro, 
Mexico (Harris et al., 2013). The sequences belonging to the Proteobacteria phyla were similar to those previously detected in salt plains and hypersaline sediments (Caton and Schneegurt, 2012; Emmerich et al., 2012).

The presence of the representatives of phyla Euryarchaeota, Bacteroidetes, Cyanobacteria and Proteobacteria has been demonstrated by this study which focuses on microbial composition of Jazan sabkha.

Acknowledgements. The authors would like to thank King Abdulaziz City for Science and Technology (KACST) for supporting out this work under grands No. 33-874 and 33-875. This study was also supported by Anadolu University Scientific Research Projects Commission under the grant no: 091001.

\section{REFERENCES}

[1] Akili, W., Torrance, J.K. (1981): The development and geotechnical problems of sabkha, with preliminary experiments on the static penetration resistance of cemented sands. Quarterly Journal of Engineering Geology and Hydrogeology 14:59-73.

[2] Anton, J., Oren, A., Benlloch, S., Rodriguez-Valera, F., Amann, R., Rossello, R. M. (2002): Salinibacter ruber, an new species of extremely halophilic bacteria from saltern crystallizer ponds. - Int. J. Syst. Evol. Microbiol. 52:485-491.

[3] Arahal, R. D., Dewhirst, E. F., Paster, J. B., Volcani, E. B., Ventosa, A. (1996): Phylogenetic analyses of some extremely halophilic Archaea isolated from Dead Sea water, determined on the basis of their 16S rRNA sequences. - Applied and Environmental Microbiology 62:3779-3786.

[4] Baati, H., Guermazi, S., Gharsallah, N., Sghir, A., Ammar, E. (2010): Novel prokaryotic diversity in sediments of Tunisian multipond solar saltern. - Research in microbiology 161:573-582.

[5] Basyoni, M.H., Aref, M.A. (2015): Sediment characteristics and microfacies analysis of Jizan supratidal sabkha, Red Sea coast, Saudi Arabia. - Arabian Journal of Geosciences 8:9973-9992.

[6] Caton, I.R., Schneegurt, M.A. (2012): Culture-independent analysis of the soil bacterial assemblage at the Great Salt Plains of Oklahoma. - Journal of basic microbiology 52:1626.

[7] DasSarma, P., DasSarma, S. (2012): Halophiles, eLS. - Wiley, New York. www.els.net.

[8] DeLong E.F. (1992): Archaea in coastal marine environments. - Proceedings of the National Academy of Sciences 89:5685-5689.

[9] Dereeper, A., Guignon, V., Blanc, G., Audic, S., Buffet, S., Chevenet, F., Dufayard, J.F., Guindon, S., Lefort, V., Lescot, M., Gascuel, O., Claverie, J.M. (2008): Phylogeny.fr: robust phylogenetic analysis for the non-specialist. - Nucleic acids research 36:W465W469.

[10] Dhowian, A. W. (2015): Laboratory simulation of field preloading on Jizan sabkha soil. Journal of King Saud University - Engineering Sciences. DOI: 10.1016/j.jksues.2015.09.001

[11] Dyall-Smith, M. (2009): The halohandbook-protocols for haloarchaeal genetics, pp. 1215, 38-40. Version 7.1. Martinsried, Germany. http://www.haloarchaea.com/resources/halohandbook/Halohandbook_2009_v7.1.pdf

[12] Edgar, R.C. (2004): MUSCLE: multiple sequence alignment with high accuracy and high throughput. - Nucleic acids research 32:1792-1797.

[13] El Hidri, D., Guesmi, A., Najjari, A., Cherif, H., Ettoumi, B., Hamdi, C., Boudabous, A., Cherif, A. (2013): Cultivation-dependant assessment, diversity, and ecology of haloalkaliphilic bacteria in arid saline systems of southern Tunisia. - BioMed research international 2013:648141. doi: 10.1155/2013/648141. 
[14] Emmerich, M., Bhansali, A., Lösekann-Behrens, T., Schröder, C., Kappler, A., Behrens, S. (2012): Abundance, distribution, and activity of $\mathrm{Fe}(\mathrm{II})$-oxidizing and $\mathrm{Fe}(\mathrm{III})-$ reducing microorganisms in hypersaline sediments of Lake Kasin, southern Russia. - Applied and environmental microbiology 78:4386-4399.

[15] Harris, J.K., Caporaso, J.G., Walker, J.J., Spear, J.R., Gold, N.J., Robertson, C.E., Hugenholtz, P., Goodrich, J., McDonald, D., Knights, D., Marshall, P., Tufo, H., Knight, R., Pace, N.R. (2013): Phylogenetic stratigraphy in the Guerrero Negro hypersaline microbial mat. - The ISME journal 7:50-60.

[16] Holguin, G., Vazquez, P., Bashan, Y. (2001): The role of sediment microorganisms in the productivity, conservation and rehabitation mangrove ecosystems: an overview. - Biol. Fertil. Soils. 33: 265-278.

[17] Kim, J.S., Makama, M., Petito, J., Park, N.H., Cohan, F.M., Dungan, R.S. (2012): Diversity of bacteria and archaea in hypersaline sediment from Death Valley National Park, California. - MicrobiologyOpen 1:135-148.

[18] Kim, O.S., Cho, Y.J., Lee, K., Yoon, S.H., Kim, M., Na, H., Park, S.C., Jeon, Y.S., Lee, J.H., Yi, H., Won, S., Chun, J. (2012): Introducing EzTaxon-e: a prokaryotic 16S rRNA gene sequence database with phylotypes that represent uncultured species. - International Journal of Systematic and Evolutionary Microbiology 62:716-721.

[19] Lane, D.J., Pace, B., Olsen, G.J., Stahl, D.A., Sogin, M.L., Pace, N.R. (1985): Rapid determination of $16 \mathrm{~S}$ ribosomal RNA sequences for phylogenetic analyses. - Proceedings of the National Academy of Sciences 82:6955-6959.

[20] Li, C.Q., Liu, W.C., Zhu, P., Yang, J.L., Cheng, K.D. (2011): Phylogenetic diversity of bacteria associated with the marine sponge Gelliodes carnosa collected from the Hainan Island coastal waters of the South China Sea. - Microbial ecology 62:800-812.

[21] Li, W., Godzik, A. (2006): Cd-hit: a fast program for clustering and comparing large sets of protein or nucleotide sequences. - Bioinformatics 22:1658-1659.

[22] Li, X., Yu, H.Y. (2012): Characterization of an organic solvent-tolerant $\alpha$-amylase from a halophilic isolate, Thalassobacillus sp. LY18. - Folia Microbiol. 57:447-453.

[23] McKay, C.P., Rask, J.C., Detweiler, A.M., Bebout, BM, Everroad RC, Lee JZ, Chanton JP, Mayer MH, Caraballo AAL, Kapili B, Al-Awar M, Al-Farraj A. (2016): An Unusual Inverted Saline Microbial Mat Community in an Interdune Sabkha in the Rub'al Khali (the Empty Quarter), United Arab Emirates. - PloS one 11(3):e0150342. doi:10.1371/journal.pone.0150342.

[24] Meklat, A., Sabaou, N., Zitouni, A., Mathieu, F., Lebrihi, A. (2011): Isolation, taxonomy, and antagonistic properties of halophilic actinomycetes in Saharan soils of Algeria. Applied and environmental microbiology 77:6710-6714.

[25] Mesbah, N.M., Abou-El-Ela, S.H., Wiegel, J. (2007): Novel and unexpected prokaryotic diversity in water and sediments of the alkaline, hypersaline lakes of the Wadi An Natrun, Egypt. - Microbial Ecology 54:598-617.

[26] Montalvo-Rodriguez, R., Vreeland, R.H., Oren, A., Kessel, M., Betancourt, C., LópezGarriga, J. (1998): Halogeometricum borinquense gen. nov., sp. nov., a novel halophilic archaeon from Puerto Rico. - International journal of systematic bacteriology 48:13051312.

[27] Oren, A. (2010): Industrial and environmental applications of halophilic microorganisms. - Environ. Technol. 31:825-834.

[28] Powers, R.W., Ramirez, L.F., Redmond, C.D., Elberg, E.L. (1966): Geology of the Arabian peninsula. - Geological survey professional paper 560:1-147.

[29] Saralov, A.I., Kuznetsov, B.B., Reutskikh, E.M., Baslerov, R.V., Panteleeva, A.N., Suzina, N. E. (2012): Arhodomonas recens sp. nov., a halophilic alkane-utilizing hydrogen-oxidizing bacterium from the brines of flotation enrichment of potassium minerals. - Microbiology 81:582-588.

[30] Solanki, P., Kothari, V. (2012): Metal tolerance in halotolerant bacteria isolated from saline soil of Khambhat. - Res Biotechnol. 3:01-11. 
[31] Solomon, E., Viswalingam, K. (2013): Isolation, characterization of halotolerant bacteria and its biotechnological potentials. - IJSRET 4:1-7.

[32] Tang, J., Zheng, A.P., Bromfield, E.S., Zhu, J., Li, S.C., Wang, S.Q., Deng, Q.M., Li, P. (2011): 16S rRNA gene sequence analysis of halophilic and halotolerant bacteria isolated from a hypersaline pond in Sichuan, China. - Annals of Microbiology 61:375-381.

[33] Verma, A., Mual, P., Mayilraj, S., Krishnamurthi, S. (2015): Tamilnaduibacter salinus gen. nov., sp. nov., a halotolerant gammaproteobacterium within the family Alteromonadaceae, isolated from a salt pan in Tamilnadu, India. - International journal of systematic and evolutionary microbiology 65:3248-3255.

[34] Wang, X., Han, Z., Bai, Z., Tang, J., Ma, A., He, J., Zhuang, G. (2011): Archaeal community structure along a gradient of petroleum contamination in saline-alkali soil. Journal of Environmental Sciences 23:1858-1864.

[35] Xu, X.W., Wu, Y.H., Wang, C.S., Oren, A., Zhou, P.J., Wu, M. (2007): Haloferax larsenii sp. nov., an extremely halophilic archaeon from a solar saltern. - International journal of systematic and evolutionary microbiology 57:717-720. 